\title{
Variation in daily flight activity and foraging patterns in colonies of uruçu - Melipona scutellaris Latreille (Apidae, Meliponini)
}

\author{
Leonardo Monteiro Pierrot ${ }^{1} \&$ Clemens Schlindwein ${ }^{2}$
}

\author{
${ }_{1}^{1}$ Instituto Xingo. Rodovia Juscelino Kubitschek, SE 206 Km 52, Zona Rural, 49820-000 Canindé do São Francisco, Sergipe, \\ Brasil. E-mail: leonardopierrot@hotmail.com \\ ${ }^{2}$ Corresponding author. Departamento de Botânica, Universidade Federal de Pernambuco, Avenida Professor Moraes Rêgo, \\ Cidade Universitária, 50670-901 Recife, Pernambuco, Brasil. E-mail: schlindw@ufpe.br
}

\begin{abstract}
The flight activities of five colonies of Melipona (Michmelia) scutellaris Latreille, 1811 kept among mixed fruit crop plantations in within fragments of Atlantic Rainforest in Pernambuco, NE-Brazil was examined. The daily deployment of foragers to collect pollen, nectar, resin and mud was observed. The colonies performed between 2,640 and 14,250 flights per day. Variations in the number of total daily flights were similar between colonies on all observation days. Proportional allocation of foragers to the different resources also among colonies showed similar variation. More than $90 \%$ of the pollen collection flights were made early in the morning. Nectar was collected in similar proportional frequencies with a reduction in activity at noon. On a single day, was observed atypical intense pollen foraging during the afternoon by all colonies. This indicates a high plasticity in foraging behaviour and efficient recruitment to resources which are presented by mass flowering trees with synchronised big bang or multiple bang flowering. Resource availability of the surrounding vegetation, therefore, seems to be the major factor in defining the forager activities on a given day.
\end{abstract}

KEY WORDS. Apoidea, foraging behavior, northeastern Brazil, stingless bees.

Stingless bees (Meliponini) show a pantropical distribution and are important pollinators of melittophilous plants in tropical rain forests (KerR \& MaUle 1964, Michener 1979, RoubiK 1989). While the foraging behaviour of Apis mellifera Linnaeus, 1758 has been studied in detail, there is little information about the foraging patterns of stingless bees.

How workers in stingless bees colonies are allocated to collect particular resources may depend on the availability and quality of resources in the surrounding vegetation. The immediate needs of the colony, internal conditions such as the quantity of pollen, honey or resin stored and reproductive phases may further define what resources are collected and to what intensity. Competition for floral resources by coexisting highly eusocial species was thought to play a major role in determining foraging behaviour patterns in Meliponini (Hubbell \& JoHNSON 1977, 1978, RoubiK 1980). Roubiк (1989) emphasises that bee foraging patterns are determined both by extrinsic and intrinsic variables that vary among species.

The genus Melipona Illiger, 1806 is amply distributed in the neotropics, occurring from N-Mexico to Tucuman and Missiones in Argentina and includes approximately 40 species (MOURE \& KERR 1950, Michener 2000). Uruçu (Brazilian name for Melipona (Michmelia) scutellaris Latreille, 1811) is endemic to the Northern Atlantic Rainforest and occurs from Rio Grande do Norte to S-
Bahia (Schwarz 1932, Nogueira-Neto 1997). The species is now extremely rare because of the deforestation of the Atlantic Rainforest for sugar cane plantations. Destructive exploration of wild colonies to obtain the valuable honey, which is traditionally used as medicine has further reduced natural colonies dramatically.

Recently, JARAU et al. (2000) and HrNCIR et al. (2000) studied recruitment behaviour in M. scutellaris and M. quadrifasciata Lepeletier, 1836. They showed that M. scutellaris recruits nestmates to foraging sites. Direction was communicated more accurately than distance. Initially nestmates were primed to search for food at random while bees leaving the hive in the second phase were provided with information about the location of food resources. It is still not known how they communicate. Guiding flights and scent marking have been excluded as communication manners (HRNCIR et al. 2000). In other species of Melipona, acoustic signals and scent markings are used to communicate the localization of food resources (MicHENER 1974, Nogueira-Neto 1997: 90-92).

In this study was asked: 1) How many foraging flights does a colony of M. scutellaris perform per day? 2) How are foraging flights distributed along a day? and 3) Do colonies from the same locality show a uniform foraging pattern, allocating workers to the different resources in the same proportion of their colony force? 


\section{MATERIAL AND METHODS}

\section{Study site}

The study was carried out at the "Granja São Saruê" $\left(07^{\circ} 49^{\prime} 34^{\prime \prime} \mathrm{S}, 34^{\circ} 58^{\prime} 14^{\prime \prime} \mathrm{W}\right.$, alt. $\left.115 \mathrm{~m}\right)$ in the Município of Igarassu, Pernambuco, NE Brazil from October 2001 to January 2002. This is the time of year when maximum flowering occurs. The study area is characterised as having fragments of secondary Atlantic Rain Forest at different stages of recuperation in a mosaic together with mixed plantations of fruit crops with Syzygium jambos (Linnaeus, 1753) Alston - rose apple, jambo, S. cumini (Linnaeus, 1753) Skeels - jambolan, jamelão, Eugenia uniflora Linnaeus, 1753 Surinam cherry, pitanga (Myrtaceae), Artocarpus heterophyllus Lam., 1789 - jackfruit (Moraceae), Malpighia emarginata Sessé \& Moc. ex DC., 1824 acerola (Malpighiaceae), Cocos nucifera Linnaeus 1753 - coconut palm (Arecaceae), Passiflora edulis Sims, 1818 - passion fruit, maracujá (Passifloraceae), Manihot esculenta Crantz, 1766 - cassava, mandioca (Euphorbiaceae), Ipomoea batatas (Linnaeus, 1753) Lam. - sweet potato (Convolvulaceae), and sugar cane monocultures (Saccharum officinarum Linnaeus, 1753, Poaceae).

The climate is tropical, hot and humid throughout the year. Annual rainfall is about $2000 \mathrm{~mm}$ and mean annual temperature is $25.5^{\circ} \mathrm{C}$.

\section{Bee colonies}

Stingless bees of various species like Melipona (Michmelia) scutellaris, M. (Melipona) subnitida Ducke, 1910, Frieseomelitta varia (Lepeletier, 1836), F. doederleini (Friese, 1900), Plebeia flavocincta (Cockerell, 1912), P. minima (Gribodo, 1893), Scaptotrigona sp. and Tetragonisca angustula (Latreille, 1811) are kept at the study site in meliponaries. All these species are native to the humid Atlantic Rainforest except M. subnitida which ordinarily occurs in the dry caatinga-region. Thirty honeybee colonies are also kept at this study site.

From approximately 300 hives of $M$. scutellaris kept at São Saruê, five strong colonies which had been maintained in wooden hives for two years or more were selected. The colonies were not fed artificially.

\section{Monitoring of the colonies}

The hives were monitored during five days showing similar climatic conditions (bright sky with passing clouds, no rain), between October 2001 and January 2002. On every hour the bees returning to each hive was counted. Counting of the bees started at 5:00, when there was light enough to visualise the individuals and terminated at 17:25 $\mathrm{h}$. Soon after sundown the number of returning bees rapidly diminished. The counts were made during five minutes each hour for each colony.

Worker bees returning to the hive were classed into one of five activity categories: collecting pollen, nectar, resin, mud or taking out waste. Bees were counted for each activity separately. Foragers which returned to the hive without any visible resource collected were considered to have collected nectar. The removal of dead individuals, rests of construction material, etc. from the hive were characterised as removal of waste. The number of bees which removed waste from the hive and returned with empty corbiculae were subtracted from the total number of workers which returned without resources so as not to artificially inflate the number of nectar foragers.
Total flight activity and comparisons between colonies

Total flight activity of the colonies were calculated using average number of workers returning for two consecutive hours. Total flight activity of the colonies per day were calculated by summing these values for the whole day.

In order to be able to compare behaviour between hives and to detect possible patterns in the collection of particular resources during the day, the absolute numbers for flight activities were converted into relative ones (number of flights per hour and resource x 100/total number of flights per day and colony).

\section{Statistics}

It was used the Kruskal-Wallis test and Mann-Whitney $U$ test (SIEGel 1975). All results with a p $=0.05$ (two-tailed) were considered significant.

\section{RESULTS}

\section{Variations in flight activity between colonies during the day}

M. scutellaris foragers performed between 2640 and 14250 flights per day (Tab. I). During the five days of observation, the monitored colonies showed a similar variation in the total number of daily flights. Colony 4 was the most active with an average of 10562 flights per day and colony 3 the weakest with an average of 4769 flights (Fig. 1).

Table I. Number of worker bees of Melipona scutellaris returning to their hive per day, during five days of observation.

\begin{tabular}{crrrrr}
\hline Colonies & $26 . X .2001$ & $24 . X I .2001$ & $5 . X I I .2001$ & $20 . X I I .2001$ & $22 . I .2002$ \\
\hline 1 & 5,712 & 5,466 & 6,078 & 7,434 & 3,360 \\
2 & 10,902 & 9,162 & 10,962 & 10,620 & 3,138 \\
3 & 7,164 & 4,860 & 3,300 & 5,880 & 2,640 \\
4 & 11,886 & 10,278 & 10,194 & 14,250 & 6,204 \\
5 & 5,814 & 5,118 & 6,786 & 8,202 & 2,898 \\
\hline
\end{tabular}

The variation in the number of daily flights during the five observation days was similar for all colonies. Most flights were recorded between 5:00-7:00 $\mathrm{h}$ and more than $60 \%$ of flight activities were concentrated within the first four hours. Flight activities during the first two hours composed $24,7 \%$ (20.XII.2001) to $43,2 \%$ (22.I.2002) of the daily total. Between 11-13:00h was noted a decline in the number of flights (Fig. $2 \mathrm{a}, \mathrm{b}, \mathrm{d}, \mathrm{e})$ followed by an increase until 15-16:00 $\mathrm{h}$.

The colonies foraging flights at one hour intervals during any one day showed similar frequencies of workers returning. Activity peaks were between 5:00-7:00 h (Fig. 2a-e).

\section{Variations of resource collection during the day}

Pollen and nectar collections accounted for more than $90 \%$ of flights from the five colonies with exception of one day (26.X.2001) when bees collected more mud. 

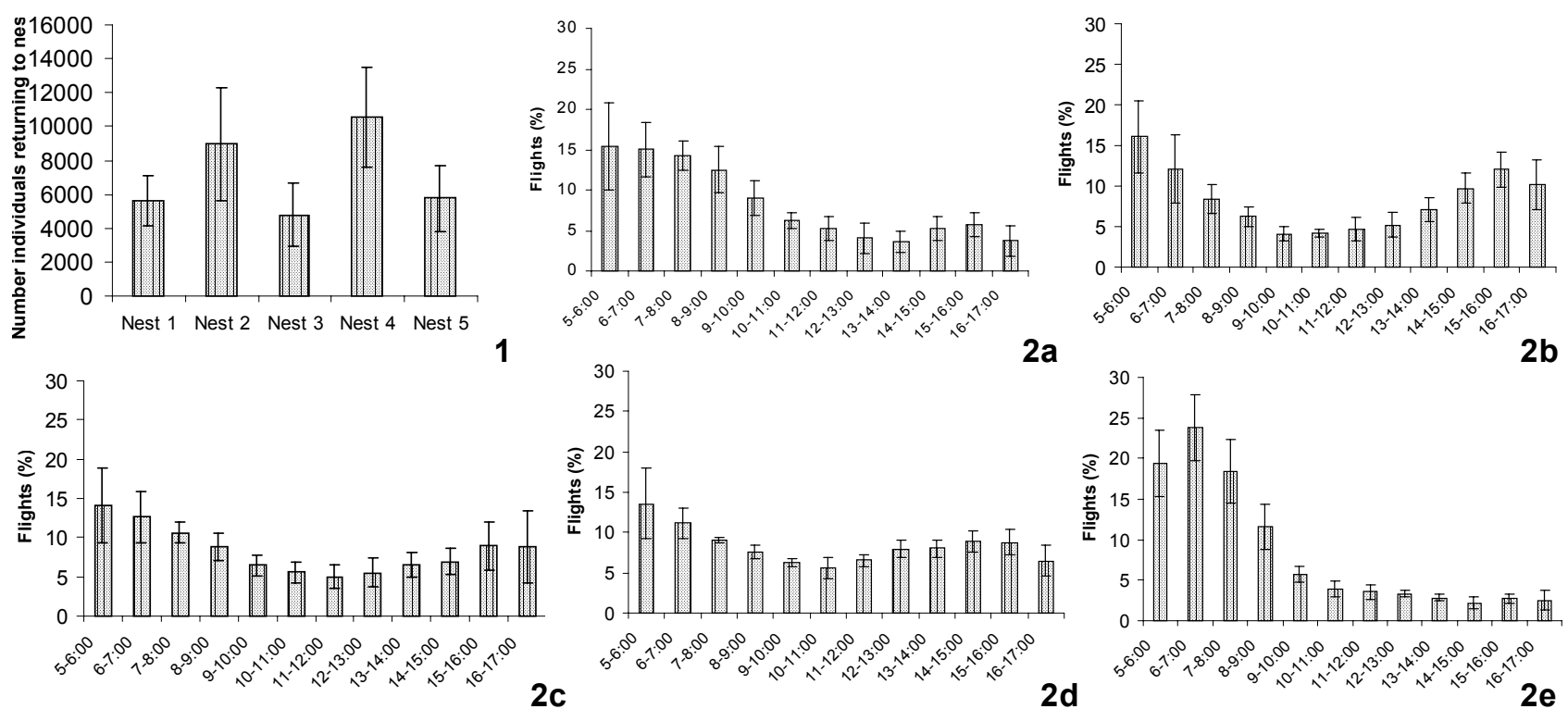

Figures 1-2. Total number of daily flights of worker bees of five colonies of Melipona scutellaris. (1) Middle and standard deviation of five days of observation, significant differences existed among the studied colonies, $\mathrm{N}=25, \mathrm{H}=87.6, \mathrm{gl}=4, \mathrm{p}<0.001$. (2) Per hour, during five observation days: (a) 26.X.2001, (b) 24.XI.2001, (c) 5.XII.2001, (d) 20.XII.2001, (e) 22.I.2002.
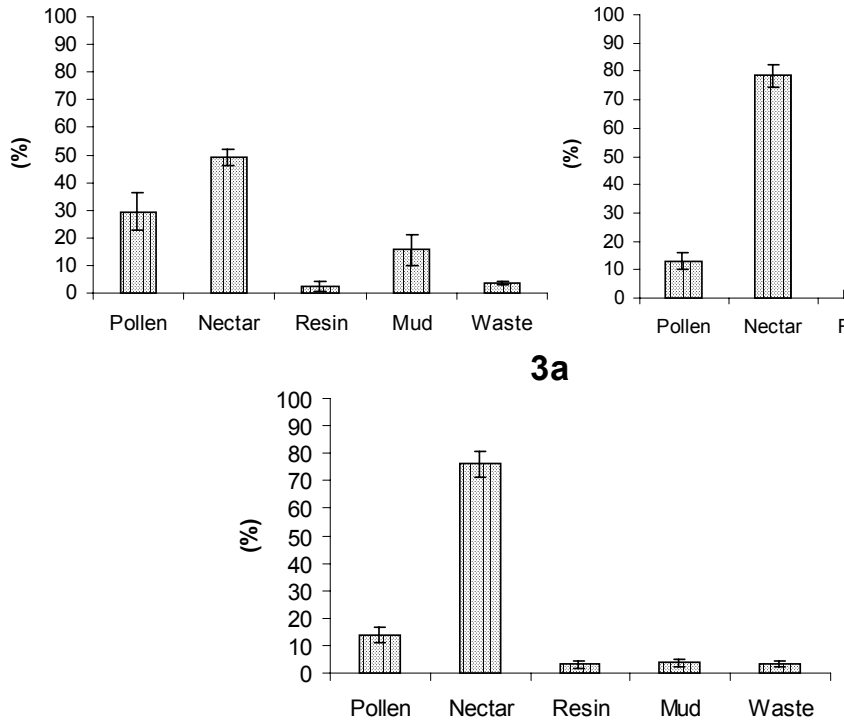

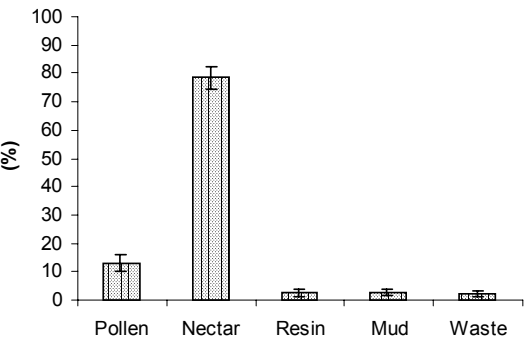

3b

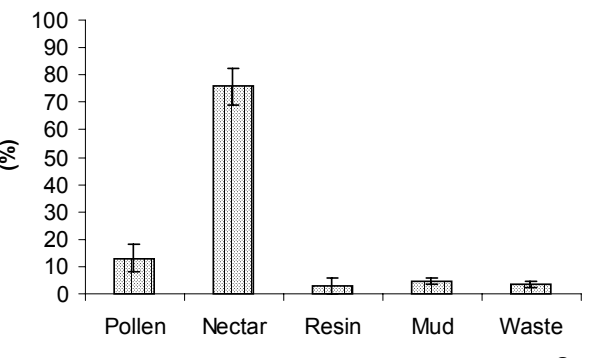

3d

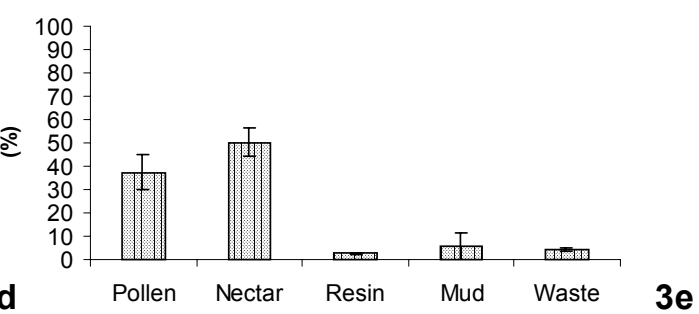

Figure 3. Total number of daily flights of worker bees of $M$. scutellaris, divided into the categories: pollen, nectar, resin, mud and waste: (a) 26.X.2001, (b) 24.XI.2001, (c) 5.XII.2001, (d) 20.XII.2001, (e) 22.1.2002.

Nectar foraging (foragers returning with empty corbiculae) was the most abundant activity in all colonies, oscillating between 50 and $80 \%$ of total flights. Pollen foraging took up to $30 \%$ of total activity (26.X.2001) with a minimum of $12 \%$ on 24.XI.2001 (Fig. 3a-e).

Resin collection accounted for 0.7 and $5.6 \%(x=2.7$, standard deviation $(\mathrm{sd})=1.7)$ of the flights of the five colonies on average and was highest on colony 5 at 5.XII.2001 (8.05\%). Mud collection varied from day to day from between $2.7 \%$ (sd $=1,0)$ at $24 \cdot X I \cdot 2001$ and $15.7 \%(\mathrm{sd}=5.6)$ at 26.X.2001 of total flight activity.

The quantity of removals of waste from the colonies was uniform and took up 3.4\% (sd = 1.2) of flight activity on average.

Revista Brasileira de Zoologia 20 (4): 565-571, dezembro 2003 


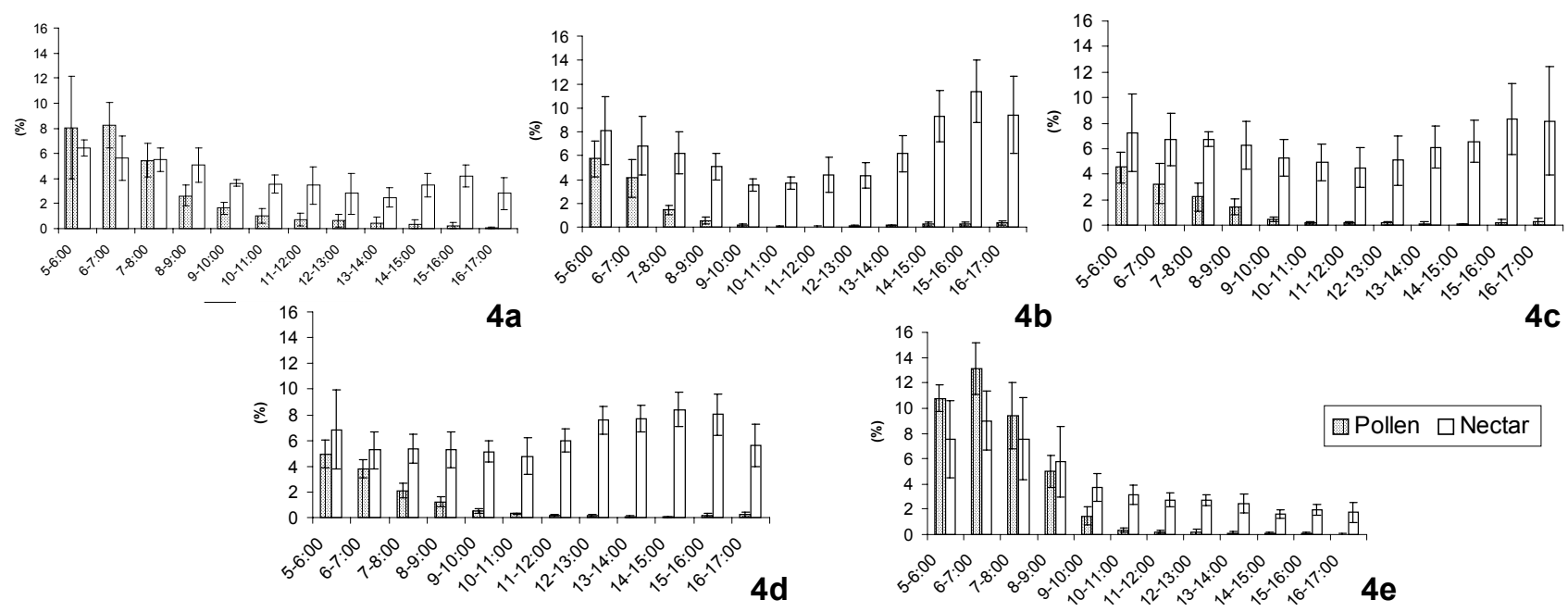

Figure 4. Relative number of pollen and nectar foraging flights of worker bees of $M$. scutellaris along the day: (a) 26.X.2001, (b) 24.XI.2001, (c) 5.XII.2001, (d) 20.XII.2001, (e) 22.1.2002.
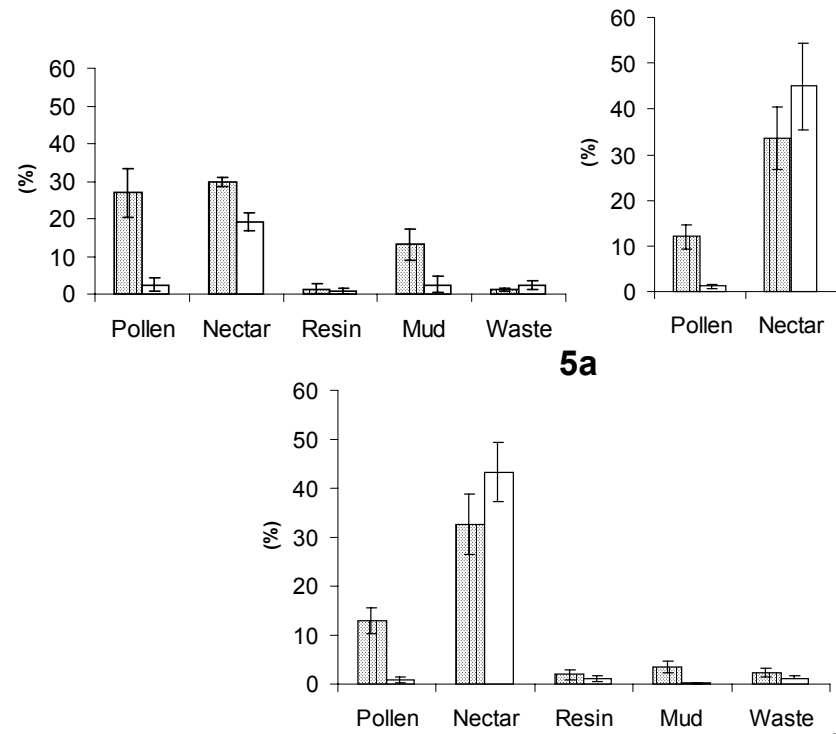
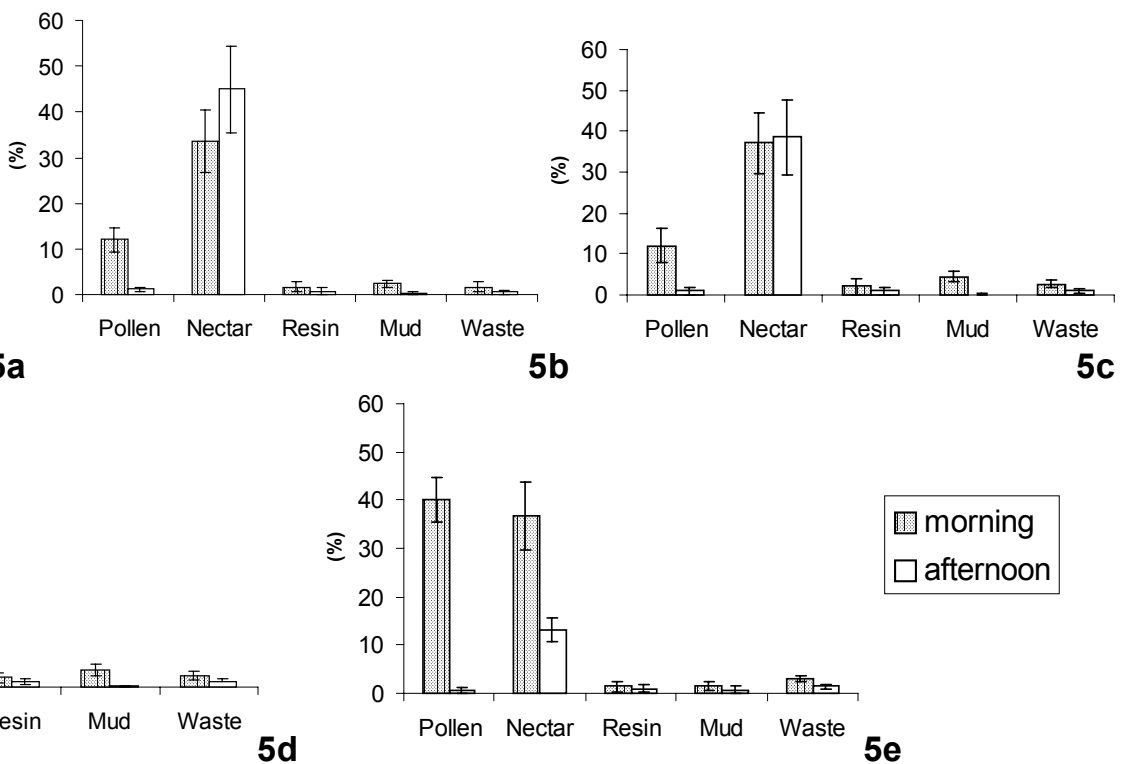

Figure 5. Relative number of daily flights of worker bees of $M$. scutellaris, during morning hours (5:00 to 11:00 $h$, grey bars) and afternoon (11:00 to 17:00 h, white bars) and categories: pollen, nectar, resin, mud and removal of waste: (a) 26.X.2001 (pollen: $n_{1}=$ 5, $n_{2}=5, U=0, p=0.004$ ), (nectar: $\left.n_{1}=5, n_{2}=5, U=0, p=0.004\right) ;(b) 24 . X I .2001$ (pollen: $\left.n_{1}=5, n_{2}=5, U=0, p=0.004\right)$, (nectar: $\mathrm{n}_{1}=5, \mathrm{n}_{2}=5, \mathrm{U}=5, \mathrm{p}=0.075$ ); (c) 05.XII.2001 (pollen: $\mathrm{n}_{1}=5, \mathrm{n}_{2}=5, \mathrm{U}=0, \mathrm{p}=0.004$ ), (nectar: $\mathrm{n}_{1}=5, \mathrm{n}_{2}=5, \mathrm{U}=11, \mathrm{p}=0.421$ ); (d) 20.XII.2001 (pollen: $n_{1}=5, n_{2}=5, U=0, p=0.004$ ), (nectar: $\left.n_{1}=5, n_{2}=5, U=2, p=0.016\right) ;(e) 22.1 .2002\left(\right.$ pollen: $n_{1}=5, n_{2}=5, U$ $=0, p=0.004)$, (nectar: $\left.n_{1}=5, n_{2}=5, U=0, p=0.004\right)$.

\section{Pollen and nectar collection during the day}

More than $90 \%$ of the pollen collection flights were made between 5:00 and 9:00 h. All colonies showed a gradual reduction in pollen collection during the day (Fig. 4a-e). Nectar foraging flights, in contrast, showed a more uniform distribution during the day. On 24.XI, 5.XII and 20.XII.2001 nectar foraging showed a reduction between 10 and 13:00h and a second peak in the afternoon (Fig. 4b-d), was more intense than that in the morning. On 22.I.2002 nectar collection flights reduced continuously from 7:00h onward (Fig. 4e).

Revista Brasileira de Zoologia 20 (4): 565-571, dezembro 2003 


\section{Spread of activities during the day}

In all colonies and on all days, pollen foraging in the morning was statistically more intense than in the afternoon (Fig. 5). Nectar collection was significantly more intense in the morning on three days (Fig. 5a, d, e) but not on others (Fig. 5b, c).

On all days resin collection flights were evenly distributed between morning and afternoon and mud was collected more frequently in the morning (Fig. 5). Waste was removed more frequent in the morning except on one day (26.10.01) (Fig. 5a).

\section{Pollen foraging in the afternoon}

On 21.I.2002, one day before our planned monitoring visit, collection activities in the morning were similar to that of the other monitored days. From the beginning of afternoon onwards, however, was recorded a high number of worker bees (at about 50 bees per minute) of M. scutellaris returning with full pollen loads to the hives. This intense pollen foraging was observed in all colonies (monitored colonies and further colonies of $M$. scutellaris maintained at the study site by the bee keeper) during the afternoon. At the end of afternoon (1717:30 h) clouds of some thousand worker bees with full scopae, hovered for several minutes near the bee stands. In the afternoon of the following day, flights, in general, were not frequent.

\section{DISCUSSION}

\section{Intraspecific variation of flight activities}

The study shows, that different colonies of M. scutellaris at the same locality show a similar distribution of flight activities proportional to the individual force of each colony. The variation in the total number of flights and the number of flights allocated for the collection of a particular resource during a day were similar. When comparing differences in the number of total flights per day or relative number of flights for particular periods during a day between the observation days, variation occurred in all colonies in the same way. High nectar collecting activity in the afternoon, in one colony, for instance, was followed by similarly high rates of nectar collection in the other colonies. Foraging activity, therefore, did not show intraspecific variation within the same location.

The quality and abundance of the resources available result, therefore, in different foraging intensities of $M$. scutellaris colonies and might explain the high variation of the total number of daily flights. In this context, it would be interesting to test whether the lack of a certain resource in the hive (after honey removal, for example) shifts foraging activities towards the missing resource. BiEsMEIJER et al. (1999a) showed, that colonies of the central American species Melipona beecheii Bennett, 1831 reacted to experimentally induced pollen stress with a higher allocation of foragers to pollen collection and intensified individual pollen foraging. General foraging activity, however, did not increase.

The number of daily flights of the monitored M. scutellaris colonies are higher than those observed for 4 Melipona species in Panama (daily flights in M. fasciata Latreille, 1811 up to 8756, M. marginata Lepeletier, 1836 up to 604, M. compressipes (Fabricius, 1804) up to 3840, M. fuliginosa Lepeletier, 1836 up to 3048) (Roubik \& Buchmann 1984).

\section{Daily foraging patterns}

All colonies showed the same foraging patterns. Pollen was almost exclusively collected in the morning showing a peak in the first two hours followed by a gradual decrease during the day. Early pollen collection activity seems to be characteristic for $M$. scutellaris and coincides with observations of experienced local uruçú - beekeepers (Sr. Chagas, R. Barbosa, R. Cantarelli pers. comm.). In four other species of Melipona, RoubiK \& BUCHMANN (1984) also observed pollen foraging early in the morning and nectar collection in the late morning hours and the afternoon.

Among stingless bees, only workers of the genus Melipona vibrate flowers with poricidal anthers legitimately (BUCHMANN 1983, Guibu et al. 1988, Rоивік 1989). All reports of Trigona Jurine, 1807 workers which explore buzz-pollination flowers refer to a specialised destructive pollen collection behaviour (RENNER 1983, RoubiK 1989). During former field work (unpublished data) we recorded numerous visits of $M$. scutellaris worker bees at buzz pollination flowers such as Solanum Linnaeus, 1753, Ouratea Aubl., 1775 (Ochnaceae) and Melastomataceae. Several plant species with poricidal anthers among the food plants of different species of Melipona are mentioned in other studies (Engel \& Dingemans-Bakels 1980, Absy et al. 1984, Ramalho et al. 1990, Marques-Souza et al. 1995, Wilms et al. 1997, Harter et al. 2002). In most of these plants anthesis initiates early in the morning and the flowers present their pollen already with the beginning of anthesis (BuCHMAnN 1983). Pollen presentation early in the morning seems to be a general pattern of melittophilous rainforest trees (FrankIE et al. 1983). The pollen foraging pattern of $M$. scutellaris observed in this study might be, at least partially, explained by their preferred exploration of buzz pollination plants.

At noon, general flight activity in all colonies was reduced. This may be associated with the scarcity of food resources. Most pollen flowers which opened in the morning are already empty or closed by noon while sources of nectar do not start nectar production until the afternoon (eg. several Malvaceae and Lamiaceae). Different species of Melipona prefer nectar flowers with high sugar concentrations (of up to 60\% and more Roubiк \& Buchmann 1984, Roubiк et al. 1995, BIESMEIJER et al. 1999b). Nectar with such high sugar concentrations seem to be more abundant in the afternoon and several species show gradual increases of nectar concentration in insolated flowers (RoubiK \& Buchmann 1984, RoubiK et al. 1995). This could explain increased nectar foraging by M. scutellaris in the afternoon.

High temperatures at noon could be another reason for the decline in the flights as has also been observed in various solitary bee species (Herrera 1990). Dehydration at high temperatures, however, might not affect $M$. scutellaris workers as this species occurs in moist tropical rainforest climate were relative humidity of the air is high.

\section{Behavioural plasticity of M. scutellaris}

The intense pollen collection that was observed at all hives on January $21^{\text {st }}$, was atypical and not repeated on following days. This demonstrates behavioural plasticity of $M$. scutellaris and shows that colonies may temporarily switch to pollen collection in the afternoon when, extraordinarily, this resource is offered in abundance. Collection activity, therefore, appears to be controlled simply by the quantity of the resources available. 
From short film recordings made on that afternoon, can be estimated that more than 50 workers per minute arrived at the hive entrance with full pollen loads. This gives a total of about 10.000 flights in four hours and would correspond to seven days of pollen foraging on "typical" days (taking the five-day-average of the five monitored hives - 1355 pollen collection flights per day). Analyses of the pollen loads of foragers on that day showed that they collected pollen from a single plant species. It was probably a mass flowering tree with a big bang or multiple bang flowering strategy (sensu GeNTRY 1974), as pollen collection in all colonies was extraordinarily weak on the following day.

The efficient exploration of mass flowering plants is important in many species of highly eusocial Meliponini and Apis mellifera (WiLms 1996, Wilms et al. 1996, SCHLINDWEIN 1998). High flexibility in the exploration of floral resources during the day implies an efficient recruitment behaviour for M. scutellaris.

\section{ACKNOWLEDGEMENTS}

We thank Sr. Chagas, for the permission to work in his meliponary and his friendly help and hospitality, Eduardo Pinto da Silva for his help in the field, Dr. Celso Feitosa Martins (UFPB, João Pessoa), Dr. Abd Al-Ghzawi (Jordan University) and Dr. Antonio Souto (UFPE, Recife) for valuable comments on the manuscript and Dr. Bob Allkin (Royal Botanical Gardens, Kew) for improving the English and comments. The study was supported by grants from CNPq.

\section{REFERENCES}

Absy, M.L.; J.M.F. Camargo; W.E. Kerr \& I.P.A. Miranda. 1984. Espécies de plantas visitadas por Meliponinae (Hymenoptera: Apidae), para coleta de pólen na região do Médio Amazonas, Revista Brasileira de Biologia, Rio de Janeiro, 44 (2): 227-237.

Biesmejer, J.C.; M. Born; S. LukÁcs \& M.J. Sommejer. 1999a. The response of the stingless bee Melipona beecheii to experimental pollen stress, worker loss and different levels of information input. Journal of Apicultural Research, Cardiff, 38 (1-2): 33-41.

Biesmejer, J.C.; M.J.A.P. Smeets; A.P. Richter \& M.J. Sommejer. 1999b. Nectar foraging by stingless bees in Costa Rica: botanical and climatological influences on sugar concentration of nectar collected by Melipona. Apidologie, Les Ulis Cedex, 30: 43-55.

BuchmanN, S.L. 1983. Buzz pollination in angiosperms, p. 73113. In: C.E. Jones \& R.J. LiTTLE (Eds). Handbook of Experimental Pollination Biology. New York, Van Nostrand Reinhold Publishing, 558p.

Engel, M.S. \& F. Dingemanns-BaKels. 1980 Nectar and pollen resources for stingless bees (Meliponinae, Hymenoptera) in Surinam (South America). Apidologie, Les Ulis Cedex, 11 (4): 341-350.

Frankie, G.W.; W.A. Haber; P.A. Opler \& K.S. Bawa. 1983. Characteristics and organization of the large bee pollination system in the Costa Rican dry forest, p. 411-447. In: C.E. Jones \& R.J. LitTle (Eds). Handbook of Experimental Pollination Biology. New York, van Nostrand Reinhold Publishing, 558p.

Gentry, A.H. 1974. Flowering phenology and diversity in tro- pical Bignoniaceae. Biotropica, Lawrence, 6: 64-68.

Guibu, L.S.; M. Ramalho; A. Kleinert-Giovannini \& V.L. ImperatrizFONSECA. 1988. Exploração de recursos florais por colônias de Melipona quadrifasciata (Apidae: Meliponinae). Revista Brasileira de Biologia, Rio de Janeiro, 48 (2): 299-305.

Harter, B., C. Leistikow, W. Wilms, B. Truylio \& W. Engels. 2002. Bees collecting pollen from flowers with poricidal anthers in a south Brazilian Araucaria forest: a community study. Journal of Apicultural Research, Cardiff, 40 (1-2): 9-16.

Herrera, C.M. 1990. Daily pattern of pollinator activity, differential pollinating effectiveness, and floral resource availability, in a summer-flowering mediterranean shrub. Oikos, Lund, 58: 277-288.

Hrncir, M.; S. Jarau; R. Zucchi \& F.G. Barth. 2000. Recruitment behavior in stingless bees, Melipona scutellaris and $M$. quadrifasciata. II. Possible mechanisms of communication. Apidologie, Les Ulis Cedex, 31: 93-113.

HubBelL, S.P. \& L.K. Johnson. 1977. Competition and nest spacing in a tropical stingless bee community. Ecology, Washington, 58 (5): 949-963.

. 1978. Comparative foraging behavior of six stingless bee species exploiting a standardized resource, Ecology, Washington, 59 (6): 1123-1136.

JaraU, S.; M. HRNCIR; R. ZuCCHI \& F.G. BARTH. 2000. Recruitment behavior in stingless bees, Melipona scutellaris and M. quadrifasciata. I. Foraging at food sources differing in direction and distance. Apidologie, Les Ulis Cedex, 31: 81-91.

KeRR, W.E. \& V. MAULE. 1964. Geographic distribution of stingless bees and its implications. Journal of the New York Entomological Society, New York, 72: 2-18.

Marques-Souza, A.C.; M.L. Absy; W.E. Kerr \& F.J.A. Peralta. 1995. Pólen coletado por duas espécies de meliponíneos (Hymenoptera: Apidae) da Amazônia. Revista Brasileira de Biologia, Rio de Janeiro, 55 (4): 855-864.

Michener, C.D. 1974. The social behavior of the bees. A comparative study. Cambridge, Harvard University Press, 404p. . 1979. Biogeography of the bees. Annals of the Missouri Botanical Garden, St. Louis, 66: 277-347. . 2000. The bees of the world. Baltimore, Johns Hopkins University Press, $913 p$.

Moure, J.S. \& W.E. Kerr. 1950. Sugestões para a modificação da sistemática do gênero Melípona. Dusenia, Curitiba, 1: 105129.

Nogueira-Neto, P. 1997. Vida e criação de abelhas indígenas sem ferrão. São Paulo, Editora Nogueirapis, 446p.

Ramalho, M.; A. Kleinert-Giovannini \& V.L. Imperatriz-Fonseca. 1990. Important bee plants for stingless bees (Melipona and Trigonini) and africanized honeybees (Apis mellifera) in neotropical habitats: a review. Apidologie, Les Ulis Cedex, 21: 469-488.

RENNER, S. 1983. The wide occurence of anther destruction by Trigona bees in Melastomataceae. Biotropica, Lawrence, 15: 251-256.

RouBIK, D.W. 1980. Foraging behavior of competing africanized honey bees and stingless bees. Ecology, Washington, 61: 836-845.

. 1989. Ecology and natural history of tropical bees. Cambridge, Cambridge University Press, 514p.

Roubik, D.W. \& S.L. Buchmann. 1984. Nectar selection by

Revista Brasileira de Zoologia 20 (4): 565-571, dezembro 2003 
Melipona and Apis mellifera (Hymenoptera: Apidae) and the ecology of nectar intake by bee colonies in a tropical forest. Oecologia, Berlin, 61: 1-10.

Roubik, D.W.; D. Yanega; M.S. Aluja; S.L. Buchmann \& D.W. INOUYE. 1995. On optimal nectar foraging by some tropical bees (Hymenoptera: Apidae). Apidologie, Les Ulis Cedex, 26: 197-211.

SCHLINDWein, C. 1998. Frequent oligolecty characterizing a diverse bee-plant community in a xerophytic bushland of subtropical Brazil. Studies on Neotropical Fauna \& Environment, Lisse, 33: 46-59.

Schwarz, H.F. 1932. The genus Melipona: The type genus of the Meliponidae or stingless bees. Bulletin of the American Museum of Natural History, New York, 63: 231-460.

SIELGeL, S. 1975. Estatística não-paramétrica. São Paulo,
McGraw-Hill, 350p.

WiLms, W. 1996. The highly eusocial of Boracéia: community structure, resource partitioning, and their role as pollinators. Encontro sobre Abelhas, Ribeirão Preto, 2: 196-204.

Wilms, W.; V.L. Imperatriz-Fonseca \& W. Engels. 1996. Resource partitioning between highly eusocial bees and possible impact of the introduced africanized honey bee on native stingless bees in the Brazilian Atlantic Rainforest. Studies on Neotropical Fauna and Environment, Lisse, 31: 137151.

Wilms, W.; W: L. Wendel; A. Zillikens; B. Blochtein \& W. Engels. 1997. Bees and other insects recorded on flowering trees in a subtropical Araucaria forest in southern Brazil. Studies on Neotropical Fauna and Environment, Lisse, 32: 220226.

Received in 06.III.2003; accepted in 02.X.2003. 